\title{
Model Pembelajaran Kolaboratif Teknik Pemecahan Masalah Untuk Meningkatkan Kemampuan Kreativitas Berpikir Matematika Siswa
}

\author{
Aminah Zuhriyah \\ Pendidikan Matematika, STKIP Kusuma Negara, Jakarta \\ aminah_zuhriyah@stkipkusumanegara.ac.id
}

\begin{abstract}
Abstrak
Penelitian ini bertujuan untuk mengetahui apakah ada pengaruh model pembelajaran kolaboratif teknik pemecahan masalah terhadap peningkatan kemampuan kreativitas berpikir matematika siswa kelas X-2 SMK Yatindo Bekasi. Penelitian ini menggunakan teknik kuantitatif dan metode eksperimen. Sampel penelitian ini diambil dari 2 kelas dengan teknik cluster random sampling, sehingga kelas X-2 sebagai kelompok eksperimen, dan kelas X-1 sebagai kelompok kontrol, dengan masing-masing kelompok berjumlah 30 siswa. Pengambilan data melalui tes materi persamaan linier dua variabel yang sudah dipelajari melalui implementasi pembelajaran, dan tes ini menghasilkan data kemampuan kreativitas berpikir matematika siswa yang sudah diuji validitas dan reliabilitas. Data yang diperoleh dianalisis dengan perhitungan gain ternormalisasi, statistik deskriptif dan inferensial. Kemudian dilakukan analisis untuk uji normalitas (uji kolmogorov-smirnov) dan diperoleh nilai Sig.=0,054 untuk siswa kelas eksperimen, sedang nilai Sig. $=0,086$ untuk siswa kelas kontrol, dan uji homogenitas (uji Levene's), diperoleh nilai Sig. $=0,200>0,05$ hasilnya kedua kelompok berasal dari varians yang homogen. kedua; pengujian hipotesis (uji- $t$ ) diperoleh nilai Sig. $=0,03<0,05$ hasilnya ada pengaruh model pembelajaran kolaboratif teknik pemecahan masalah untuk meningkatkan kemampuan kreativitas berpikir matematika siswa.
\end{abstract}

Kata kunci: kreativitas berpikir, pembelajaran kolaboratif, pemecahan masalah.

Dikirim: 13 September $2021 \quad$ Direvisi: 26 November $2021 \quad$ Diterima: 30 November 2021

\section{Identitas Artikel:}

Zuhriyah, A. (2022). Model Pembelajaran Kolaboratif Teknik Pemecahan Masalah Untuk Meningkatkan Kemampuan Kreativitas Berpikir Matematika Siswa. Jurnal Ilmu Pendidikan (JIP) STKIP Kusuma Negara, 13(2), 100-108.

\section{PENDAHULUAN}

Pada era abad 21 adalah zaman yang mengalami banyak perubahan karena hadirnya perkembangan teknologi yang terintegrasi ke berbagai bidang pengetahuan yang sangat pesat, sehingga perubahan tersebut menimbulkan tantangan yang harus kita hadapi bagi generasi muda dalam mengikuti perkembangan tersebut. Menghadapi tantangan di era abad 21 ini, maka generasi muda perlu memiliki empat keterampilan yang sangat penting, yaitu dua keterampilan berpikir kritis dan kreatif, komunikasi dan berkolaborasi. Pada penelitian ini akan menyoroti kemampuan berpikir kreatif yang dibangun dari proses belajar bersama dalam menyelesaikan masalah.

Penelitian sebelumnya yang dilakukan Hidayat, Susilaningsih \& Kurniawan (2018) yang mendalami empat keterampilan berpikir, salah satu dari empat kelompok keterampilan yang akan diselidiki secara mendalam adalah 
keterampilan cara berpikir. untuk mengembangkan seperangkat keterampilan berpikir. Diantara keterampilan berpikir itu adalah: 1) kreatif dan inovatif, 2) berpikir kritis dan pemecahan masalah, dan 3) belajar bagaimana mencapai kemampuan metakognitif. Keterampilan berpikir kreatif dan pemecahan masalah menjadi keterampilan berpikir penting untuk dikuasai dalam menghadapi perubahan zaman.

Salah satu pengetahuan yang dapat membantu siswa untuk menghadapi perubahan di era abad 21, dengan mempelajari pendidikan matematika. Supardi (2015) mengatakan Matematika yang diajarkan di sekolah lazim dikenal dengan matematika sekolah. Peranan matematika sekolah adalah untuk mempersiapkan siswa agar sanggup menghadapi perubahan keadaan dalam kehidupannya melalui pola berpikir matematika. Dalam pembelajaran matematika, siswa tidak terlepas dari soal-soal yang dituntut untuk menyelesaikan masalah. Sehingga penting bagi siswa memiliki kemampuan berpikir kreatif agar siswa dapat memecahkan masalah yang tertuang dalam soal-soal yang mereka hadapi dengan solusi yang kreatif karena matematika tidak selalu dapat diselesaikan dengan cara yang sama dengan sebelumnya. Hal ini juga mendorong siswa dalam kehidupan sehari-hari, mereka akan mampu menemukan solusi dari permasalahan-permasalahan yang timbul dalam masyarakat karena terlatih untuk berpikir kreatif (Utami, Endaryono \& Djuhartono, 2020).

Upaya mencapai tujuan pembelajaran matematika di era abad 21 ini terkait pada peningkatan kreativitas berpikir siswa sudah banyak cara dilakukan oleh para pendidik dan peneliti, namun upaya pengajaran dalam pembelajaran matematika masih belum berdampak pada peningkatan kemampuan kreatvitas berpikir. Oleh karena adanya kendala siswa berpikir untuk mencapai keterampilan berpikir lancar, ketrampilan berpikir luwes, ketrampilan berpikir orisinal, ketrampilan elaborasi, dan ketrampilan menilai yang merupakan ciri-ciri dari kemampuan berpikir kreatif (Moma, 2016).

Masalah sulitnya mencapai keterampilan dalam kreativitas berpikir matematika tersebut, faktanya dialami juga oleh siswa kelas X-Akuntansi di SMK Yatindo Bekasi. Hal ini terjadi saat peneliti melakuan survey untuk mengetahui hasil prestasi belajar siswa dari ujian tengah semester. Hasilnya $100 \%$ siswa memperoleh nilai diatas KKM. Dari hasil tersebut. Kasus ini menunjukkan bahwa siswa mampu menyelesaikan soal matematika dengan baik, namun saat peneliti melakukan penelitian di kelas untuk memberi contoh soal berbasis pemecahan masalah dengan materi yang sudah dipelajari ternyata semua siswa tidak dapat menjawabnya. Setelah diselidiki, ternyata guru tidak memberikan contoh soal berbasis pemecahan masalah pada materi persamaan linear dua variabel. Alasannya guru selalu mengalami kesulitan dalam melakukan evaluasi penilaian jika memberikan soal berbasis pemecahan masalah kepada siswa, banyak siswa tidak selesai menjawab soal tersebut, karena penyelesaian soal berbasis pemecahan masalah memiliki tingkat kemampuan berpikir yang tinggi, sehingga setiap diberikan soal berbasis pemecahan masalah hasilnya hampir semua siswa menjawabnya tidak memuaskan, terkadang banyak siswa tidak selesai menjawab soal tersebut.

Permasalahan dalam pembelajaran matematika di atas, kondisi ini perlu adanya terobosan dalam menerapkan model pembelajaran yang tepat dan dapat membantu siswa yang mengalami kesulitan dalam menyelesaikan soal 
matematika berbasis masalah secara individu, model pembelajaran tersebut dapat mendorong siswa untuk menciptakan pengetahuan baru yang dibangun dari hasil kreativitas berpikir siswa bersama teman sebayanya, yaitu menerapkan model pembelajaran kolaboratif teknik pemecahan masalah. Menurut para ahli bahwa pembelajaran kolaboratif dapat mengembangkan keterampilan berpikir tingkat tinggi. Siswa berkomitmen dalam proses pembelajaran kolaboratif. Selain itu siswa bekerja bersama untuk mewakili hubungan interaksi yang paling efektif, seperti ketika siswa belajar berpasangan satu orang mendengarkan sementara rekan lainnya mendiskusikan pertanyaan yang sedang diselidiki. Keduanya akan meningkatkan keterampilan pemecahan masalah dalam merumuskan ide-ide mereka, mendiskusikannya, menerima umpan balik langsung dan menanggapi pertanyaan dan komentar dari siswa lain (Laal \& Ghodsi, 2012).

Berdasarkan teori di atas, maka tujuan penelitian ini adalah untuk mengetahui apakah ada pengaruh model pembelajaran kolaboratif teknik pemecahan masalah untuk meningkatkan kemampuan kreativitas berpikir matematika siswa.

\section{Model Pembelajaran Kolaboratif}

Pembelajaran kolaboratif diperkenalkan oleh George Jardine, seorang profesor logika dan filsafat di Universitas Glasgow. Rancangan metode pembelajaran yang disebut sebagai penilaian sejawat untuk membantu dalam mempersiapkan siswa belajar untuk berpartisipasi dalam suatu komunitas pembelajaran. Saat ini, pembelajaran kolaboratif banyak digunakan di komunitas pendidikan, diantaranya di Indonesia. Pembelajaran kolaboratif menciptakan lingkungan yang dapat menghidupkan kembali dan memperkaya proses pembelajaran (Ismayati, 2018).

Menurut Laal, Geranpaye dan Daemi (2013) bahwa pembelajaran kolaboratif suatu pendekatan pendidikan yang melibatkan kelompok siswa yang belajar bersama dalam mencapai tujuan bersama untuk memecahkan masalah. Selain itu pembelajaran berbasis masalah dapat meningkatkan kemampuan berpikir kreatif siswa (Ningrum, 2016).

Laal, Geranpaye dan Daemi (2013) menambahkan bahwa ada lima elemen penting dalam pengaturan pembelajaran kolaboratif, sebagai berikut: (a) jelas interdependensi positif yang dirasakan; (b) interaksi yang cukup besar; (c) pertanggungjawaban individu dan tanggung jawab pribadi; (d) keterampilan sosial; dan (e) kelompokkan evaluasi diri. Semua elemen dasar ini diimplementasi untuk memastikan proses pembelajaran kolaboratif. Untuk Belajar bukan hanya hasil otomatis dari menuangkan atau memberikan informasi ke kepala orang lain. Diperlukan proses mental individu itu sendiri. Oleh karena itu, mengajar dengan sendirinya tidak akan pernah mengarah pada pembelajaran nyata (Silberman, 1996).

Elemen-elemen proses pembelajaran kolaboratif mengarahkan siswa untuk saling berinteraksi untuk bekerjasama dalam menyelesaikan masalah. Pendapat beberapa ahli dalam Huang (2020) bahwa budaya kerja sama tidak hanya menumbuhkan komunikasi, berbagi informasi baru, dan kerja sama tetapi juga meningkatkan partisipasi siswa di kelas dan dapat meningkatkan kreativitas siswa. Lebih jauh, budaya kerjasama berkontribusi pada efektivitas pembelajaran dan kinerja penciptaan ide kreatif, seperti identifikasi masalah, pencarian dan menentukan solusi, serta membuat ide perencanaan. 
Berdasarkan teori di atas, maka model pembelajaran kolaboratif merupakan model pembelajaran yang dirancang untuk menyelesaikan suatu soal atau masalah yang diajukan, untuk didiskusikan dan diselesaikan oleh siswa secara kelompok dengan saling bertukar pengetahuan agar mendapatkan sebuah solusi dan mampu menciptakan pengetahuan baru dari hasil proses kreativitas berpikir siswa.

\section{Pemecahan Masalah}

Pendekatan pemecahan masalah dirancang untuk membantu siswa mengembangkan keterampilan berpikir, keterampilan menyelesaikan masalah, dan keterampilan intelektualnya (Zuhriyah \& Nurimani, 2021). Senada dengan Hidayat (2018) mengatakan bahwa dengan kata lain, pembelajaran berbasis masalah melatih peserta didik untuk memiliki keterampilan berpikir tingkat tinggi. Pemecahan masalah yaitu sebuah cara yang dilakukan dalam pendidikan dan pengajaran untuk mencapai tujuan pelajaran tersebut dengan cara membiasakan peserta didik agar dapat menentukan penyelesaian suatu permasalahan, mulai dari masalah yang paling mudah hingga yang paling sulit dikerjakan sendiri (Yuhani, Zanthy \& Hendriana, 2018).

Dari teori di atas, maka disimpulkan bahwa pemecahan masalah merupakan suatu usaha menyelesaikan masalah yang berkaitan dengan kehidupan sehari-hari melalui proses berpikir dan tahapan yang sudah ditentukan.

\section{Kreativitas berpikir Matematika}

Matematika merupakan ilmu universal yang mempunyai peran penting dalam berbagai disiplin ilmu dan mengembangkan daya piker manusia, serta mendasari perkembangan teknologi modern. Oleh karena itu, mata pelajaran matematika perlu diberikan kepada semua peserta didik dari jenjang sekolah dasar hingga jenjang sekolah lanjut untuk membekali peserta didik dengan kemampuan berpikir logis, analisis, sistematis, kritis dan kreatif serta dapat menyelesaikan masalah yang dihadapinya dalam kehidupan sehari-hari (Maskuri, 2019)

Pendapat para ahli yang dikutip oleh Fardah, (2012) menjelaskan beberapa hal tentang kreativitas berpikir dapat diartikan dengan berpikir kreatif, ini yang harus siswa kembangkan dengan mengeksplorasi permasalahan yang memberikan banyak solusi, sehingga dapat meningkatkan kemampuan siswa dalam bepikir kreatif. Untuk mengidentifikasi dan mengenali kemampuan siswa berpikir kreatif dapat dilakukan dengan mengembangkan tugas atau tes berpikir kreatif. Membandingkan dan membuat hubungan antara kemampuan berpikir kreatif dengan ketrampilan lainnya dapat memperkaya wawasan guru akan potensi atau bakat yang dimiliki siswa-siswanya.

Kemampuan berpikir kreatif mengacu pada kemampuan memecahkan masalah. Di sini, pertanyaan divergen dapat meningkatkan dan membangun kreativitas siswa Pertanyaan yang berbeda membutuhkan lebih banyak dari 1 jawaban. Mereka membutuhkan tingkat berpikir siswa yang tinggi. Siswa harus mampu mengingat beberapa informasi. Mereka juga harus menerapkan pengetahuan lain untuk menggambarkan, mengeksplorasi, dan menganalisis topik, situasi atau masalah (Sitorus, 2020). Lebih lanjut, kemampuan berpikir kreatif merupakan kemampuan banyak menemukan kemungkinan jawaban terhadap suatu masalah, dimana penekanannya pada kuantitas, ketepatgunaan, dan keberagaman jawaban (Utami dkk., 2020). Dimana jawaban yang dimaksud 
merupakan jawaban yang benar dan bervariasi. Munandar menambahkan bahwa ciri-ciri kemampuan berpikir kreatif sebagai berikut.

Pertama adalah fluency (keterampilan berpikir lancer), yaitu memiliki ciri-ciri seperti mencetuskan banyak pendapat, jawaban dan penyelesaian masalah, memberikan banyak cara atau saran dalam melakukan berbagai hal dan selalu memikirkan lebih dari satu jawaban. Kedua adalah flexibility (keterampilan berpikir luwes), yaitu keterampilan memberikan gagasan, jawaban atau pertanyaan yang bervariasi, dapat melihat suatu masalah dari sudut pandang yang berbeda-beda, mencari banyak alternatif, pemecahan yang berbeda-beda dan mampu mengubah cara pendekatan. Ketiga adalah originality (keterampilan berpikir orisinil), yaitu kemampuan melahirkan gagasan baru dan unik, memikirkan cara yang tidak lazim untuk mengungkapkan diri dan mampu membuat kombinasi yang tidak lazim. Keempat adalah elaboration (keterampilan memperinci), yaitu kemampuan memperkaya dan mengembangkan suatu gagasan atau produk, dan menambahkan atau memperinci secara detail dari suatu situasi sehingga lebih menarik.

Kemampuan berpikir kreatif matematika adalah meningkatkan kemampuan pikir siswa, untuk mengenal konsep, rumus, prinsip dan hal-hal yang berkaitan pada pengetahuan matematika dengan cara mempelajari dan menghubungnya dalam suatu masalah, sehingga dapat membangun pengetahuan baru.

\section{METODE PENELITIAN}

Penelitian ini dilakukan pada bulan Agustus Tahun 2019 dengan menggunakan pendekatan kuantitatif dan metode eksperimen berupa pemberian treatment pembelajaran matematika dengan model pembelajaran kolaboratif teknik pemecahan masalah kemudian dianalisis apakah terdapat peningkatan kemampuan kreativitas berpikir matematika siswa. Dalam penelitian ini penulis akan menggunakan dua kelas yaitu satu kelas sebagai kelas eksperimen yang belajar menerapkan model pembelajaran kolaboratif teknik pemecahan masalah, dan satu kelas sebagai kelas kontrol yang belajar menerapkan model konvensional. Populasi penelitian ini seluruh siswa kelas X semester Ganjil SMK Yatindo bekasi tahun akademik 2019/2020. Pengambilan sampel menggunakan teknik cluster random sampling, yaitu mengambil satu kelas dijadikan sebagai eksperimen dan satu sebagai kelas kontrol. Adapun kelas eksperimen yang dipilih kelas X-2, sedang kelas kontrol dipilih kelas X-1. Setelah pembelajaran selesai, kedua kelompok siswa diberikan tes essay untuk melihat kemampuan kreativitas berpikir matematika siswa pada materi persamaan linear dua variabel.

Untuk memperoleh data dalam penelitian ini, penulis menggunakan pengumpulan data berupa data dari hasil tes materi persaman dua linier, data ini digunakan untuk mengetahui kemampuan kreativitas berpikir matematika. Hasil belajar matematika kemampuan kreativitas berpikir matematika siswa bertujuan untuk menguji kebenaran hipotesis dari sejumlah soal yang sudah di validitas dan reabilitas. Teknik pengujian hipotesis yang digunakan untuk penelitian ini adalah uji- $t$ dengan uji prasyarat analisis yaitu uji normalitas dan uji homogenitas. 


\section{HASIL DAN PEMBAHASAN}

Siswa eksperimen yang menerapkan model pembelajaran kolaboratif teknik pemecahan masalah ini pembelajaran menggunakan soal berbasis masalah sebagai media bagi siswa untuk membangun konsep matematika, ini berikan kesempatan siswa untuk melakukan eksplorasi, sintesis dan menperolehkan informasi terkait temuan konsep yang akan diterapkan. Artinya siswa terlebih dahulu menentukan masalah dan mengintegrasikan pengetahuan baru berdasarkan pengalaman yang sudah dimiliki dan dapat diaplikasikan konsep secara nyata. Langkah-langkah ini dapat membangun kemampuan kreativitas berpikir matematika siswa. Media belajar dalam penelitian ini berupa soal berbasis pemecahan masalah yang diberikan untuk siswa kelas eksperimen, lihat contohnya pada Tabel 1 sebagai berikut.

Tabel 1. Bentuk Soal Berbasis Pemecahan Masalah Dan Penyelesaiannya

\begin{tabular}{|c|c|}
\hline Soal & $\begin{array}{l}\text { Pada suatu hari Ayu dan Rini bersama-sama pergi ke pasar membeli } \\
\text { mangga dan jeruk. Ayu membeli } 2 \mathrm{~kg} \text { manga dan } 1 \mathrm{~kg} \text { jeruk dengan } \\
\text { harga Rp } 4.000,00 \text {. Rini membeli } 3 \mathrm{~kg} \text { mangga dan } 4 \mathrm{~kg} \text { jeruk dengan } \\
\text { harga Rp } 8.500,00 \text {. Berapakah harga } 1 \mathrm{~kg} \text { mangga }\end{array}$ \\
\hline Masalah yang & Pembelian 1; mangga $2 \mathrm{~kg}$ dan $1 \mathrm{~kg}$ jeruk seharga $\mathrm{Rp} 4.000,00$ \\
\hline di ketahui & Pembelian 2; mangga $3 \mathrm{~kg}$ dan $4 \mathrm{~kg}$ jeruk seharga $\mathrm{Rp} 8.500,00$ \\
\hline $\begin{array}{c}\text { Masalah yang } \\
\text { belum } \\
\text { diketahui }\end{array}$ & Berapakah harga $1 \mathrm{~kg}$ mangga \\
\hline $\begin{array}{c}\text { Model } \\
\text { matematika }\end{array}$ & $\begin{array}{l}\text { Misal: mangga }=x, \text { jeruk }=y \\
2 \mathrm{~kg} \text { mangga }(2 x)+1 \mathrm{~kg} \text { jeruk }(y)=\operatorname{Rp} 4.000,00 \\
3 \mathrm{~kg} \text { mangga }(3 x)+4 \mathrm{~kg} \text { jeruk }(4 y)=\operatorname{Rp} 8.500,00 \\
\text { Maka model matematika; } \\
2 x+y=\operatorname{Rp} 4.000,00 \\
3 x+4 y=\operatorname{Rp} 8.500,00\end{array}$ \\
\hline Penyelesaian & $\begin{array}{l}\text { Penyelesaian soal ini menggunakan konsep metode eliminasi } \\
2 x+y=4.000|3| 6 x+3 y=12.000 \\
3 x+4 y=8.500|2| 6 x+8 y=17.000- \\
-5 y=-5.000 \\
y=1.000 \\
y=1000 \text { adalah Rp } 1000,00 \text { untuk harga } 1 \mathrm{~kg} \text { jeruk } \\
\text { Berapa harga } 1 \mathrm{~kg} \text { manga } \ldots \ldots \ldots ? \\
y=1000 \text { disubstitusi ke }--2 x+y=4.000,00 \\
2 x+1000=4000,00 \\
2 x=3000,00 \\
x=1500,00 \\
x=1500,00 \text { adalah } \mathrm{Rp} 1500,00 \text { untuk harga } 1 \mathrm{~kg} \text { mangga }\end{array}$ \\
\hline & Harga $1 \mathrm{~kg}$ mangga adalah $\mathrm{Rp} 1.500,00$ \\
\hline
\end{tabular}

Dalam penyelesaian permasalah di atas, dari langkah-langkahnya siswa belajar berpikir untuk menyelesaikan permasalahan tersebut. Ini menunjukan adanya aktivitas pemecahan masalah dengan menerapkan keterampilan mengamati masalah, menganalisis, menyelesaikan masalah dan sampai menentukan kesimpulan. Senada dengan Barkley, Cross \& Major (2014) mengatakan bahwa pembelajaran kolaboratif teknik pemecahan masalah dalam proses langkahlangkahnya dapat membantu siswa belajar mengidentifikasi, menganalisis, dan 
menyelesaikan masalah dengan cara terorganisir dan model pembelajaran ini tidak membuat siswa jenuh atau kewalahan.

Dari data penelitian, diperoleh hasil yang menunjukkan bahwa rata-rata tes kemampuan kreativitas berpikir matematika siswa kelas eksperimen yang menerapkan model pembelajaran kolaboratif teknik pemecahan masalah lebih tinggi dengan nilai rata-rata kemampuan kreativitas berpikir matematika siswa yaitu 16,60, sedangkan siswa kelas kontrol yang menerapkan model pembelajaran konvensional lebih rendah dengan nilai rata-rata kemampuan kreativitas berpikir matematika yaitu 15,60. Kemudian data diuji analisis, yaitu uji normalitas dan homogenitas. Hasil pengelolaan data untuk uji normalitas memperoleh nilai sig hitung untuk siswa kelas eksperimen sebesar Sig. $=0,054>\alpha=0,05$, sedang siswa kelas kontrol memperoleh nilai Sig. $=0,086>\alpha=0,05$, maka disimpulkan bahwa data kedua kelompok berdistribusi normal. Sedang uji homogenitas, memperoleh nilai Sig. $=0,200>\alpha=0,05$ artinya Ho ditolak, maka disimpulkan bahwa data dari kedua kelompok berasal dari varians yang homogen. Dari perhitungan statistik diperoleh nilai uji $t_{\text {hitung }}=2.134>t_{\text {tabel }}=2.000$ atau nilai Sig. $=0,037<\alpha=0,05$, dengan derajat kebebasan $(d k)=58$, berarti Ho ditolak, maka disimpulkan bahwa ada pengaruh model pembelajaran kolaboratif teknik pemecahan masalah untuk meningkatkan kemampuan kreativitas berpikir matematika siswa.

Dari hasil uji- $t$, menunjukkan adanya pengaruh model pembelajaran kolaboratif teknik pemecahan masalah untuk meningkatkan kemampuan kreativitas berpikir matematuika siswa. Hal ini dapat dibuktikan dari pendapat para ahli yang dikumpulkan oleh Zhou dkk. (2020) bahwa kolaborasi didefinisikan sebagai interaksi yang efektif dalam kelompok yang menumbuhkan tindakan saling tergantung dan status yang adil, dan kelancaran kreatif, dan sebagai kemampuan siswa untuk menghasilkan sejumlah ide-ide baru. Selain itu model pembelajaran kolabaratif teknik pemecahan masalah ini, penerapannya dilakukan secara kelompok dan cara kerjanya mendorong siswa untuk mendiskusikan masalah dan diselesaikan bersama. Pendapat tersebut diperkuat teori dari para ahli bahwa pembelajaran kolaboratif juga menumbuhkan budaya kerja sama, meningkatkan kemampuan komunikasi, berbagi informasi baru, dan kerja sama tetapi juga meningkatkan partisipasi siswa di kelas, sehingga menumbuhkan kreativitas siswa (Inui, Wheeler \& Lankford, 2006). Hal ini didukung juga dari teori beberapa para ahli yang dikumpulkan oleh Windasari dan Cholily (2021) bahwa berpikir kreatif yang merupakan kemampuan siswa untuk menyelesaikan suatu permasalahan dari berbagai macam solusi dan Naimnule, Kartono dan Asikin (2020) kemampuan berpikir kreatif adalah keahlian dalam memecahkan soal kompleks.

Banyaknya dukungan para ahli, hal ini membuktikan bahwa model pembelajaran kolaboratif teknik pemecahan masalah adalah suatu cara guru membantu siswa untuk meningkatkan kreativitas berpikir matematika dengan belajar bersama menyelesaikan masalah. Dalam penelitian ini, bahwa pengaruh model pembelajaran kolaboratif teknik pemecahan masalah yang dirancang secara kelompok, sehingga dapat memberikan kontribusi untuk meningkatkan kegigihan siswa bersama teman sebayanya dalam penyelesaian tugas atau soal berbasis masalah agar dapat meningkatkan kemampuan berpikir untuk menciptakan gagasan melalui proses diskusi dan perdebatan, selain itu siswa dilibatkan secara aktif dalam proses pembelajaran untuk menemukan dan memperoleh pengetahuan 
baru yang dibangun dari proses berpikir kreatif siswa dalam menyelesaikan tugas atau soal, kemampuan siswa ini akan dapat mengembangkan kurikulum pembelajaran.

\section{KESIMPULAN}

Kegiatan belajar kelompok melalui model pembelajaran kolaboratif dengan pendekatan pemecahan masalah untuk melatih kemampuan siswa dalam menyelesaikan berbagai masalah matematika materi persamaan linear dua variable dalam bentuk soal berbasis masalah yang berkaitan dengan masalah kehidupan sehari-hari yang harus diselesaikan melalui proses kerjasama atau berdiskusi bersama teman sebayanya sehingga muncul hasil kreativitas berpikir matematika siswa untuk menjawab soal yang diberikan. Melatih meningkatkan kemampuan kreativitas berpikir matematika ini melalui model pembelajaran kolaboratif teknik pemecahan masalah sebagai modal siswa kelas X-Akuntansi di SMK Yatindo Bekasi untuk menghadapi tantangan di era abad 21.

\section{UCAPAN TERIMA KASIH}

Kami mengucapkan terima kasih kepada ketua dan staf Lembaga Penelitian dan Pengabdian Masyarakat STKIP Kusuma Negara Jakarta atas arahan dan bimbingan ketika peneliti dalam melakukan penelitian hingga tersusun artikel ini.

\section{REFERENSI}

Barkley, E. E., Cross, K. P., \& Major, C. H. (2016). Collaborative Learning Techniques: Teknik-teknik Pembelajaran Kolaboratif. Nusa Media.

Fardah, D. K. (2012). Analisis proses dan kemampuan berpikir kreatif siswa dalam matematika melalui tugas open-ended. Kreano, Jurnal Matematika Kreatif-Inovatif, 3(2), 91-99. https://doi.org/10.15294/kreano.v3i2.2616.

Hidayat, A. (2018). Pengaruh model pembelajaran berbasis masalah dengan pendekatan pemecahan masalah terhadap kemampuan komunikasi matematis siswa smp negeri 1 rumbio jaya. Jurnal Cendekia: Jurnal Pendidikan Matematika, 2(1), 23-40. https://doi.org/10.31004/cendekia.v2i1.30.

Hidayat, T., Susilaningsih, E., \& Kurniawan, C. (2018). The effectiveness of enrichment test instruments design to measure students' creative thinking skills and problem-solving. Thinking Skills and Creativity, 29, 161-169. https;//doi.org/10.1016/j.tsc.2018.02.011.

Huang, C. E. (2020). Discovering the creative processes of students: Multi-way interactions among knowledge acquisition, sharing and learning environment. Journal of Hospitality, Leisure, Sport \& Tourism Education, 26, 100237. https://doi.org/10.1016/j.jhlste.2019.100237

Inui, Y., Wheeler, D., \& Lankford, S. (2006). Rethinking tourism education: What should schools teach. Journal of Hospitality, Leisure, Sport and Tourism Education, 5(2), 25-35. https://doi.org/10.3794/johlste.52.122

Ismayati, E. (2018). The design of collaborative learning for teaching physics in vocational secondary school. IOP Conference Series: Materials Science and 
Engineering, $\quad 336(1), \quad 012040 . \quad$ https;//doi.org/10.1088/1757899X/336/1/012040.

Laal, M., Geranpaye, L., \& Daemi, M. (2013). Individual accountability in collaborative learning. Procedia-Social and Behavioral Sciences, 93, 286-289. https://doi.org/10.1016/j.sbspro.2013.09.191.

Laal, M., \& Ghodsi, S. M. (2012). Benefits of collaborative learning. Procediasocial and behavioral sciences, 31, 486-490. https://doi.org/10.1016/j.sbspro.2011.12.091

Maskuri, S. (2019). Media Pembelajaran Matematika. Deepublish.

Moma, L. (2016). Pengembangan instrumen kemampuan berpikir kreatif matematis untuk siswa SMP. Delta-Pi: Jurnal Matematika dan Pendidikan Matematika, 4(1), 27-41. http://dx.doi.org/10.33387/dpi.v4i1.142

Naimnule, M., Kartono, K., \& Asikin, M. (2020). Mathematics problem solving ability in terms of adversity quotient in problem based learning model with peer feedback. Unnes Journal of Mathematics Education Research, 9(2), 222228.

Ningrum, P. N. (2016). Meningkatkan keaktifan dan kemampuan berpikir kreatif melalui pembelajaran kolaboratif berbasis masalah materi kelarutan dan hasil kali kelarutan (ksp) siswa kelas XI SMA Negeri 10 Semarang. Jurnal Pendidikan Sains (JPS), 4(1), 17-28. https://doi.org/10.26714/jps.4.1.2016.1728

Sitorus, J. (2020). Students Math Creative Thinking Skill. IJER (Indonesian $\begin{array}{llll}\text { Journal of } & \text { Educational }\end{array}$ https://doi.org/10.30631/ijer.v5i1.66

Supardi, U. S. (2015). Peran berpikir kreatif dalam proses pembelajaran matematika. Formatif: Jurnal Ilmiah Pendidikan MIPA, 2(3), 248-262. http://dx.doi.org/10.30998/formatif.v2i3.107.

Utami, R. W., Endaryono, B. T., \& Djuhartono, T. (2020). Meningkatkan Kemampuan Berpikir Kreatif Matematis Siswa Melalui Pendekatan OpenEnded. Faktor: Jurnal Ilmiah Kependidikan, 7(1), 43-48. http://dx.doi.org/10.30998/fjik.v7i1.5328

Windasari, A. D., \& Cholily, Y. M. (2021). Analisis Kemampuan Berpikir Kreatif Siswa Memecahkan Masalah HOTS dalam Setting Model Kooperatif Jigsaw. Jurnal Cendekia: Jurnal Pendidikan Matematika,5(1), 623-631. https://doi.org/10.31004/cendekia.v5i1.462.

Yuhani, A., Zanthy, L. S., \& Hendriana, H. (2018). Pengaruh Pembelajaran Berbasis Masalah terhadap Kemampuan Pemecahan Masalah Matematis Siswa SMP. JPMI (Jurnal Pembelajaran Matematika Inovatif), 1(3), 445-452. https://doi.org/10.22460/jpmi.v1i3.445-452.

Zhou, N., Kisselburgh, L., Chandrasegaran, S., Badam, S. K., Elmqvist, N., \& Ramani, K. (2020). Using social interaction trace data and context to predict collaboration quality and creative fluency in collaborative design learning environments. International Journal of Human-Computer Studies, 136, 102378. https://doi.org/10.26714/jps.4.1.2016.17-28

Zuhriyah, A., \& Nurimani, N. (2021). Pendekatan pemecahan masalah untuk meningkatkan pemahaman konsep matematika siswa SMK. Jurnal Inovasi Penelitian, 2(1), 1-6. https://doi.org/10.47492/jip.v2i1.596. 